Indonesian Journal of Global Health Research

Volume 1 Number 1, November 2019, pp. 39 - 46

e-ISSN 2715-1972; p-ISSN 2714-9749

http://jurnal.globalhealthsciencegroup.com/index.php/IJGHR

\title{
VERBAL ABUSE ON PRE-SCHOOL CHILDREN: THE CASE OF INDONESIAN CHILDREN
}

\author{
Andriyani Mustika Nurwijayanti*, Muhammad Khabib Burhanuddin Iqomh \\ Program Studi Sarjana Keperawatan, Sekolah Tinggi Ilmu Kesehatan Kendal, Jln Laut 31A \\ Kendal, Jawa Tengah, Indonesia, 51311 \\ *andri.manis78@yahoo.co.id
}

\begin{abstract}
Verbal abuse is a form of violence received by children in the form of words that hurt the children. The impact of verbal abuse on children causes them to behave aggressively, emotional disturbances, and personality disorders. To explore this phenomenon, this research was designed employing descriptive approach. 132 children (henceforth, respondents)were randomly recruited. The age of respondents ranged from 32 to 34 years.The majority of were high school students with $116(87.9 \%)$ in number, while otehrs were housewives, 113 respondents $(85 \%)$ in number. Data in this study were collected through questionnaire. The data were then analyzed descriptively. The results of this showed that light verbal abuse were received by 15 respondents $(11.4 \%)$ and heavy verbal abuse by 117 respondents $(88.6 \%)$.
\end{abstract}

Keywords: verbal abuse, pre-school children, parents

\begin{tabular}{|c|c|c|}
\hline $\begin{array}{c}\text { First Received } \\
\text { 30 September } 2019\end{array}$ & $\begin{array}{c}\text { Revised } \\
05 \text { November } 2019\end{array}$ & $\begin{array}{c}\text { Accepted } \\
12 \text { November } 2019\end{array}$ \\
\hline $\begin{array}{c}\text { Final Proof Receivec } \\
20 \text { November } 2019\end{array}$ & & $\begin{array}{c}\text { Published } \\
30 \text { November } 2019\end{array}$ \\
\hline $\begin{array}{l}\text { How to cite (in APA style) } \\
\text { Nurwijayanti, A, M, Iqmah, M, } \\
\text { indonesian children. Indone }\end{array}$ & $\begin{array}{l}\text { (2019). Verbal at } \\
\text { urnal of Global He }\end{array}$ & $\begin{array}{l}\text { pre-school children: the case of } \\
\text { search, } 1(1), 39-46 \text {. }\end{array}$ \\
\hline
\end{tabular}

\section{INTRODUCTION}

Verbal abuse can occur anytime and anywhere. Children are at risk of getting verbal abuse treatment both in the playground and at home. Verbal abuse experienced by children can come from their playmates as well as parents or family members where the child lives. The family functions as a place for the first time to obtain an education and first place to shelter. However, there are some children who do not obtain a sense of comfort when in the midst of the family. One of the actions causing the loss of a child's sense of comfort is verbal abuse. Verbal abuse received by the child will cause developmental disorders in children (Ujang, 2011).

The development and growth of children progress gradually in accordance with the stages of age. The success of the stages of development is influenced by stimuli obtained by children both directly and indirectly. These stimuli can come from parents as the closest environmentas well as the environment in which the children carry out socialization. A good stimulus will help the child develop according to the stage of his age, while a bad stimulus will inhibit development and one of the bad stimuli is the verbal abusepada child (Soetjiningsih, 2013).

Growth and development are an inseparable unity in a child's life. Growth can be observed and seen directly. The growth is an event of increasing body mass that can be 
measured in units of centimeters and kilograms. While development is the functioning of bodily organs that can be measured by certain methods, children who encounterverbal abuse cause them complicated to socialize. The impacts of children who experience verbal abuse include confined themselves, the existence of fear, and children will be overwhelmed with sadness, lack of confidence, and aggressive. Longterm impact will result in recurring events in the form of a chain of violence on the family, imitating the experience experienced, apathy, disruption of social relations and even self-harming behavior until death (Hurlock, 2011).

The Center for Integrated Services for the Empowerment of Women and Children reported that the incidence of child abuse in 2014 was divided into several forms, namely: $60 \%$ sexual violence, $30 \%$ physical violence, $4.3 \%$ psychological violence, and other forms of violence which is $5.7 \%$, whereas in 2015 sexual violence was $80 \%$, physical violence was $20 \%$. Verbal abuse is the worst in the form of child neglect $50.5 \%$, physical violence $18 \%$, sexual violence $9.3 \%$, emotional violence $8.5 \%$ and other violence $10.8 \%$ (Adriana, 2010).

The family is the closest environment to where the child does a series of activities. Families should be a shelter for children sometimes no longer provide comfort. This is due to the violent behavior of parents towards their children. Parents expect their children to obey what they are told to do, once they do not obey their commands, they will obtain a penalty (Soetjiningsih, 2013).

Verbal forms of abuse are various including unloving and cold, intimidation, exclusion or embarrassment of children, habit of denouncing children, rejecting children, and extreme punishment. Verbal abuse occurs because parents do not realize what they say is one of the wrong behaviors.Factors that can encourage parents to do verbal abuse on children include parental knowledge factors, parental experience factors, economic factors, and environmental factors. Knowledge factors are very influential with parents' behavior to do verbal abuse on children. This is due to knowledge is a very important domain in the formation of one's behavior. Behavior that is based on knowledge, then the behavior are long and tend to be settled, while behavior that is not based on knowledge will be temporary (Lidyasari, 2010)

It is expected that the increasing role of the family can break the chain of verbal abuse. Thus, the verbal abuse chain will be broken. Children who get the right stimulus or treatment and do not deviate will make the child's life good quality both during childhood and at a later stage.The family is the closest environment to the children. Family behavior and the behavior received by children will affect the quality of life and development of children. The family has a big role in dealing with violence received by children. families who understand deviant behavior will be able to minimize the incidence of violence against children, including verbal abuse.

Parenting provided by the family will contribute to the occurrence of verbal abuse. Parenting is a form of parenting given to their children in educating, caring, giving love according to the needs of children and forming good behavior according to applicable norms. Applying the wrong parenting will cause wrong treatment in children. One parenting that has the risk of verbal abuse in children is parenting muscle.Based on the 
explanation, wes are interested in examining the abuse of abuse in preschool children (3-6 years) in ABA Kindergarten, Weleri District, Kendal Regency, Indonesia. This study aims to determine the description of the occurrence of verbal abuse in pre-school age children.

\section{METHOD}

This study employed descriptive approach exploring the phenomenon of verbal abuse experienced by pre-school children. 132 children were selected by using random sampling technique (Hidayat, 2014). They were enrolled in ABA 2 Kindergarten in Weleri District, Middle Java, Indonesia. In this study, parents were also participated.The research tool is a facility used by researchers in collecting data to get the best results (careful, complete and systematic) so that the analysis is easier. The research tool in this study is a questionnaire based on the theory of verbal abuse. The questionnaire is a measurement tool in the form of a questionnaire or questionnaire with several questions or statements (Notoatmodjo, 2010).

Validity test of the instrument used Pearson Product Moment correlation test by comparing the value of $r$ table with $r$ count, where the instrument is considered valid if the value of $r$ count is greater than the value of $r$ table (Nursalam, 2008). Based on the results of the validity test all items declared valid items with $r$ values greater than 0.444.The reliability test result obtained was 0.910 . Thisis greater than 0.6 and close to number one, so declared reliable. Reliability shows the extent to which measurement results are relatively consistent if repeated measurements are carried out over time. In this research, an internal consistency test is performed which is to test the instrument once. If the result of the calculation is close to 1,then it is considered reliable(Nursalam, 2008). To determine the reliability of the variable statement items, a Cronbach's Alpha test is performed.The research carried out involved research assistants drawn from nursing students. The study was conducted at TK ABA 05 Weleri District, Kendal Regency.

Respondents involved in research must obtain protection of their rights and are free from coercion. The ethical principles applied in this study are benficence, human dignity and justice. The benefits of this ethical consideration are from suffering, exploitation, and consideration of risks. This right includes the right to participate in research or refuse to be a respondent in researchto obtain fair treatment and confidentiality rights are maintained (Nursalam, 2008).

\section{RESULTS}

The results of the research analysis were conducted using univariate and bivariate analyses. The results of the analysis are documented in Table 1 and 2.

Table 1

Profile of Respondents in Term of Age $(n=132)$

\begin{tabular}{ccccc}
\hline Variable & Mean & SD & Min-Max & $95 \%$ CI \\
\hline Age & 34.1 & 5.4 & $20-52$ & $32.2-34.1$ \\
\hline
\end{tabular}

Table 1 shows that the average age of the respondents is 34 (95\% CI32.2-34.1). 
Table 2.

Respondents' Characteristics of Verbal Abusein $2019(n=132)$

\begin{tabular}{lcc}
\hline \multicolumn{1}{c}{ Variable } & $\mathrm{f}$ & $\%$ \\
\hline Light Verbal Abuse & 15 & 11.4 \\
Heavy Verbal Abuse & 117 & 88.6 \\
\hline
\end{tabular}

Table 2 displays that the heavy verbal abuse is most frequently experienced by the respondents

\section{DISCUSSION}

Pre-school children are children between the ages of 3-6 years who have not attended primary school. Pre-school age children are also called the golden period (Golden period) because, the time when the child's brain's ability to absorb all forms of information is very high (Kartono, 2008).

Preschool age is between the ages of 4-5 years in which at this stage children have an increasingly expanding world after they meet close family, friends both at school and outside of school and neighbors.Pre-school age children experience a transition period that is the transition from total egocentric thoughts to social awareness and the ability to consider the viewpoint of others. In this period, language continues to develop; speaking is still a carrier of egocentric communication. Play is the most effective way to understand, adjust, and develop life experiences.Preschoolers' thoughts are often described as magical thoughts, because of their self-centeredness and transductive reasons. They believe that the mind is the most powerful, so that it puts them in a vulnerable position to feel guilty and responsible for bad thoughts.

The family has a central rolerole in helping the growth and development of children. The family behavior in this case is parents have a central role in determining the quality of growth and development of children. The family support in the form of good behavior will be a reference for children to think and behave. Bad behavior in the form of violence perpetrated by the family will provide stimulus to the child, causing disruption in achieving development according to age.

Forms of parental violence were found in the form of physical, emotional, social and economic violence and neglect of the household. Following is an explanation of the forms of parental violent behavior, namely:

a. Physical Abuse

Physical violence can occur in the household in the form of abuse. Forms of physical violence start from beating, pulling, pushing, and pinching. Physical violence consists of several kinds, such as abusing other people by using the offender's limbs (hands or feet), and torturing. Abusive physical violence were stomping, throwing and kicking.

b. Emotional / psychological violence (psychological Abuse)

Emotional violence is done from the psychological side of a woman. This happens because a woman can be humiliated through harsh words, insulting and threatening. As such, fear, loss of confidence, loss of ability to act and a sense of helplessness were present. 
c. Social and economic violence

Acts of social and economic violence usually occur when the husband forbids his wife from working, but the husband does not provide for his wife. This is due to the wife being economically dependent. A husband allows his wife to work to earn money for his interests, but is limited by space or the husband oversees the wife's activities from his social life.

d. Household neglect

Neglect is multi-dimensional (physical, sexual, emotional, social, and economic). Abandonment of children by families occurs in the economic sense. This happens because the husband cannot meet basic needs such as food, clothing, and medication (Choirunnisa, 2008).

Verbal abuse is an act in the form of yelling, cursing and frightening by using inappropriate words. Verbal abuse can occur when parents know their child is asking for attention, telling the child to be quiet and do not cry. If the child continues to talk, parents will use verbal abuse. Verbal abuse is in the form of saying words that threaten, insult, and shout.Verbal abusemen is a form of violence that does not appear in the physical form but in the form of language, a form of verbal abuse, among others: slandering, mocking others and insults in the form of words. Verbal violence is done repeatedly; the impact is that children lose the opportunity to develop their potential and abilities.

Limited family knowledge about children's growth and development causes parents to behave wrongly in treating their children. Thus, the children who are not yet able to get to know something but sometimes are forced by parents to do it and when the child is not able to do it parents will become angry, yell, berate their children. Lack of parental knowledge about children's education and lack of religious knowledge in parents can be the background of verbal abuse on children.

The experience of parents getting verbal abuse will cause parents to do verbal abuse on children. Children who get mistreated will be aggressive even after being a parent will be cruel to their children. Aggressive parents will give birth to aggressive children. This causes mental disorders with behavior that is accepted by them as a child.Parents have the obligation and responsibility to print quality children. In carrying out their responsibilities, parents play a role as a guide that directs children to reach certain stages that deliver children to be ready in life. In addition to educating, guiding, caring, parents are obliged to set a good example in living life. So parents have an important influence on children's behavior. In mentoring and educating children, every family will adopt a parenting.

The type of parenting provided by parents will have an impact on the child. Parents who apply democratic parenting and implement it well will have a good impact on children's development. Nonetheless, parents still provide limits, control, so that children continue to behave properly.Another parenting is authoritarian parenting. This parenting tends to impose the will of parents; children are required to always follow the wishes of parents and are usually accompanied by threats. In order to comply with their wishes, parents tend to force, rule, punish. This authoritarian parenting pattern also has an impact in its application. Authoritarian parenting will produce characteristics of a child who is timid, 
quiet, introverted, low initiative, and is worried that even a child can withdraw. However, authoritarian parenting has a good effect when applied in a number of situations. Authoritarian parenting can be a parenting style that is beneficial to the emotional maturity of children if the parenting is well implemented (Hafiz\&Almaududi, 2015).

\section{CONCLUSION}

The results showed the majority did severe verbal abuse.This was due to lack of knowledge from parents about verbal abuse and its effects.Prevention of verbal abuse is not only done by parents, but is done by all people who are in the environment where children live and interact. Other environments that support verbal abuse prevention include playgrounds and schools. Pre-school age children have developmental characteristics that mimic the behavior of those around them, stimuli or examples of good behavior will make children behave well and be happy in living their lives. It is necessary to increase knowledge about verbal abuse among parents and the community to increase efforts to prevent the occurrence of verbal abuse.

\section{REFERENCES}

Adriana. (2011). TumbuhKembangdan Therapy BermainpadaAnak. Jakarta: SalembaMedika.

Choirunnisa. Dampakverbal abusepadaanak.Jakarta : EGC;2008

Hafiz, S., E., \&Almaududi, A., A..(2015). polaasuhotoriterterhadapkematanganemosi yang dimoderatoriolehkesabaran. Jakarta : FakultasPsikologi, UniversitasMuhammadiyah Prof. DR. HAMKA

Hidayat, AA. (2014). Metode penelitian keperawatan dan teknis analisis data. Jakarta: Salemba Medika.

Hurlock, Elizabeth B. (2011). Psikologi Perkembangan: suatu pendekatan sepanjang rentang kehidupan. Jakarta:Erlangga.

Kartono. (2008). Perkembanganpsikologianak. Jakarta: Erlangga.

Lidyasari, A, T. (2010). Polaasuhotoritatifsebagaisaranapembentukankarakteranakdala setting keluarga.Yogyakarta: FakultasIlmuPendidikan UNY: 2010

Notoatmodjo, S. (2010). Metodologipenelitiankesehatan. Jakarta: RhinekaCipta.

Nursalam. (2008). Konsepdanpenerapanmetodologipenelitianilmukeperawatan. Jakarta: SalembaMedika.

Santrock. (2015). Life-Span Development: PerkembanganMasa-Hidup. Edisi 13.Jilid 1. AlihBahasa: Widyasinta Benedictine. Jakarta: Erlangga.

Sit, Masganti.(2017). Psikologiperkembangananakusiadini .Depok: PenerbitKencana. 
Soetjiningsih. (2013). Tumbuh Kembang Anak. Jakarta: EGC.

Ujang. (2011). KonsepDasarPerkembanganPotensiMotorikAnakUsiaPrasekolah. Tahun VIII, No 12.

Wong, D.L, Hockenberry, M., Wilson, D., Winkelstein, M.L. \& Schwartz, P. (2009).

Buku ajar keperawatanpediatrik Wong edisi: 6 (alihbahasa: Andri Hartono, Sari Kurnianingsih, Setiawan). Jakarta: EGC. 
Indonesian Journal of Global Health Research, Vol 1 No 1, November 2019, pp. 39 - 46 Global Health Science Group 